my operation was contra-indicated, for nephrectomy is not generally considered to be the operation for renal calculus. In my case the result has justified my selection. It was male on account of the uncertain diagnosis, the size of the tumor and the necessity for room for work. The kidney was so disorganized as to he functionally worthless, and if nephrotomy had been done the evilenes is in favor of a renal fistula as a result. My patient is not only relieved but is well, and recovereal rapidly.

As regards the route, I think there was hero no ahoice, for if in such a case nephrectomy is the selected operation it must be abdominal. I do not see how the operation would have been possible by the ordinary lumbar method on account of the sime of the tumor and its adhesions.

By the Kionig Jumbo-abdominal operation or similar modifications, such an extensive division of the nuscles would be necessary that the operation would become practically a transperitoneal one hefore its conclusion. Again, the abdominal route has the following advantages:

$\Lambda$ better opportunity for diagnosis.

$A$ better appreciation of the exact conditions under which the operation must be done.

An opportunity to examine the remaining kidney. More space for operation.

An ensier access to the pedicle.

(3) The dangers of the operation seem to be: (1) sloock; (2) hasmorrhage; (3) uramia; (1) peritonitis; (5) septicamia; (6) Renal listula.

(1) I have wondered at the comparatively slight constitutional disturbance and uneventful rapid recovary from so extensive an operation. The condition resembles that seen after continued exertion or great fatigue. Also at the rapidity with which the urine became normal, and the readiness with which the remaining kidney performed its increased task.

(5) The case demonstrates that it is possible to obtain a recovery by neplirectomy without drainage, and it is preferable to drainage, if followed by its frequent unsatisfactory sequel of fistula aml its attendant discomforts. This, even when the peritoneal cavity hats been tainted with fluid from a kidney extensively disorganized by a suppurative pyelo-nephritis.

No've. - l'atient last seen on July 1, 1s!'2. Was in perfect hoalth as far ats could bo ascertained.

\section{Glinital \$Department.}

\section{A CASE OW BROKLN NECK, WI'TH AUTOP'SY.}

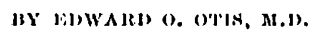

H. L. W., JR., a student, seventeen years oll, was attempting to do the "cut-lown" in the gymmasium of the institution where he was at school, when he fell upon the underlying mattress. This accident happened about five o'elock in tho afternoon of Jannary 20th. The "cut-down," at it is called in gymmasimm parlance, is a simplo feat. Tho performer stands beneath the parallel flying rings, holding them in his hamds. He swings his feet up so as to throw them inside his hands, and letting go without breaking the continuity of the swing, lands npon his feet. It is a protty and not a dillicult trick.

1 kend at the surgiend Section of the Suflolk Distriet Mentien Sociuty, May 4, 18:2\%.
Young W. when about the middlo of this manceuve, fell a distance of about five feet, upon a thiek mattress lying beneath. He fell at the point of time when his head was down and the superincumbent body was moving forwarl with the momentum of the swing. The resultant of the owo motions was that he struck upon his head - the oecipital part - and upon his knees and ellows. 'The weight of the body, then, bent over the cervical spine on the one hame, whiles the head resting on the mat, held it lixed, on the other. 'The boy weighed about a hundred and twenty-live or thirty pounds, and had a long, slender neck. 'I'ho woight of the boty, not the force of the fall, did the mischier.

As one can readily sce, no more perfecet way of breaking one's neek could bo devised; and yet in a considerable gymnasium experience I have never secen or heard of this or any accident happening in the performance of this common trick, although it possesses this awful possibility. 'There is no evidence to show that the fall was aceompanied with any great amount of pain. l'aralysis was immediate, the patient finding it impossible to extricate himself from tho peculiar position in which he had fallen. Ile wats seen by his attending physician, 1)r. Nute, of Exetcer, N. H., who had him very carefully transported to his room, near by, on a stretcher.

I saw him, togrether with 1)r. G. W. Gity, of this city, the next forenoon, seventeen hours after tho accident. There wats complete paralysis below a line drawn two or chree inches above the nipples. Ilo could flex the forearm upon the arm, but could not extend it, or make any other s.lovement of arm or hand. Respiration was diaphragmatic. 'There was paralysis of bladder and intestines. He conld rotato the heal, hut any antero-posterior movement gavo him pain. There was a tender spot, painful on pressure, between the fourth and sixth vertebras. There was no semsation in the paralyzed portion of the body. lle could swallow porfectly well, but could not clear his throat. $\Lambda$ n attempt was made by oxtension, counter-extension and manipulation to reduce whatever displacement might exist from dislocation or fracture. 'This gave him much pain and was apparently without result. Operative interference was not advised.

I saw him again the next forenoon, danuary 22 , and thenceforward constantly until the end, and mado another attempt with his attending physician to reduco whatever displacement there might bo. Extension and counter-extension with rotation was tried, and twice we heard something suap, which was also noticed by the patient, but no results followed. Wo then applied permanent extension from the occiput and chin, with a weight of from seven to twelve pounds, and counter-extension by elevating the head of tho bed. This seemed to give him relief and when it was discontinued from time to time ho often asked to have it re-ippplienl. Ho was given simple liquid nourishment, catheterized regularly, and the tympatnites was relieved by a rectal tube kept in situ. $\Lambda$ ॥ ice-bag was placed at the back of his neck. The temperature was about a degree above normal, the pulse $62^{\circ}$, and the respiration 2.1 . Il is mind was remarkably clear and ho was perlectly self-prossessed, although ho realized tho gravity of his condition. His fortitudo for one so young was remarkable; he expressed himself as having no fear, and showed the greatest care and consideration for all about him. Not the slightest 
thing escaped his notice, and he frequently suggested little devices for his own comfort.

On Saturday, January 231 , the third day after the accident, breathing became difficult, from the accumulation of mucus. This was removed from tho throat and larynx by a pair of long placental forceps with cotton. Then nitro-glycerine, one-fiftieth of a grain, was given, which had a most marvellous effect in clearing the lungs with great rapidity. The administration of this drug was continued every three or four hours up to the time of his death. Brandy and aromatic spirits of ammonia were also given from time to time. On Saturday afternoon dissolution seemed imminent, but the heroic determination of the patient to live until his mother arrived from the West, together with the happy effect of the nitro-glycerine, seemed to be the factors in averting imminent death. On Sunday, January 24 th, the fourth day after the accident, the temperature arose to $102^{\circ}$, the pulse to 96 , and the respiration to 40 . By trying to breathe as gently and quietly as possible he secmed to keep the collection of mucus at a minimum. He would sleep an hour or two at a time. Now and then for a moment he would be delirious. On Monduy, the fifth day, the temperature went up to $104^{\circ}$ in the afternoon, the respiration varied from 40 to 44 , and the pulse from 98 to $11 \%$, and at times would become very weak. Death took place early 'Tuesday morning, the sixth day after the accident.

An examination was made of the spine in the cervical region, nine or ten hours after death. Drs. W. 'T. Bull of New York, Symington of Santa Fé, New Mexico, Perry and Nute of Exeter, N. H., being present. The space between the atlas and atloid seemed to be unusually wide, but the ligaments were not torn. Neither did there appear to be any rupture of the various ligaments anywhore in the part of the spinal column examined. A fracture of the lamina of the fifth or sixth cervical vertebra was found, but no displacement. Neither was there a dislocation anywhere. On opening the spinal canal over the seat of fracture the dura was moderately injected and the spinal cord was found to be soft and difluent. The bodies of the vertebra were in place. If a dislocation or displacement occurred at the time of the accident it is probable that it immediately righted itself. 'The cord, however, was probubly crushed and irretrievably damaged at the moment of tho accident, remembering that the paralysis was inmediate. In the light of the autopsy no operation could have accomplished anything, thus verifying Moullin's statement" that "in cases of fructure by indirect violence, the operation of trephining offers little or no hope. It is probable that in the majority of cases the cord is only subjected to momentary compression, but yet it is so reduced to a pulp that recovery of function very rarely follows."

Such a case as this, however, is a most trying and unpleasant one for the surgeon, for, as Dr. Gay remarked, his inclination is to attempt some operative interference, but his judgment opposes it. 'The length of time the patient survived such an injury is remarkable and unusual I think. Operation in case of injury of the spine has been recommended since the time of Ambrose Pare, and has been not infrequently done in suitable cases, not, however, with great success. I will only refer the reader to the most exhaustive review and discussion of the subject I um aware of by Dr. J.

"'Troatise on Surgery, 1891, 1. 661.
William White, in a paper read before the American Surgical Association, last September, in Washington, and published as a reprint from the Therapeutic: Gazette of Octoher 15, 1891. In the American Journal of the Medical Sciences for April, 1892, p. 395, Cliurch and Eisendrath of Chicago report cases of spinal cord surgery.

\section{(ANCEROUS KIDNEY REM()VEI) BY LAPA- RO'TOMY; RECOVERY.}

\section{HY s. J. MNX'Plek, Nt.1).,}

suryeron, ('urne'y Hospital; Surygron to Out-1'utients, Mlassstehusetls Gencral Hosp.; Damonstrator of Anatomy, Iltervari Mled. School.

Captain I. B., age sixty, of late lighthouse-kecped and formerly' sailing-master, was sent to me in July, 1891, by Dr. Mackeen, of Cow Bay, C. B., on account of an abrominal tumor, probably renal.

Severul months before, he had stepped through a hole in the floor while groing about in the dark, and struck heavily against a beam. He was unconscious for a few minutes and on coming to found that he was severely bruised in the left side just below the ribs. He was confined to his bed for a few days, aud soon resumed his usual work.

He first consulted Dr. MacKeen on June 20, 1891, on account of hypogastric pain and henaturia. 'The: bladder was found to be distended with urine and blood-clot. Considerable quantities of fresh blood and clots were passed for nine days when the urine becam clear and has remained so ever since.

When I examined him in July, I found him to be a man of about six feet in height, weighing about two hundred pounds, and the picture of health and strength. In the left of the abdomen could be felt a hard, quites movable mass, about the size of a cocoanut, filling that side to a point between the linea alba and linea semiJunaris. There was no tenderness on pressure and no suggestion of fluid.

The position of the descendung colon was not mado out, though it would probably have been easily located had it been distended by air injection. Nothin: abnormal was to be found in the other organs or in the urine.

Dr. Fitz exumined the pationt with me, and agreed with me that the mass was probably an enlarged kidney, which, even if cancerous, was so movable as to offer a good chance for its removal.

The patient entered the ('arney Hospital, and on July $22 d$ I operated. On opening the abdomen througl the left semilunaris I found the descending colon out. side and somewhat behind the tumor. A small cut was made through the peritoneum which covered it, and by stretehing and tearing an opening of suflicient size was made for the removal of the mass, without damage to the large branches of the inferior mesenteric vessels. Gauze pads packed into the abdomina] cavity kept the intestines out of the field of operation and also prevented the blood from getting into the peritoneal cavity.

'The tumor was covered by a network of enormous veins that ruptured at the least violence, and it was necessary to work very rapidly in order to secure thes renal vessels, the hamorrhage being tremendous. As soon as the vessels could be felt and partially isolated a large clamp was placed on them and the ureter, the I lead bofore the Surgical section of the Suffolk Distriet Medien
socioty, May 4 , 16\%2. 